\title{
IN VITRO ANTIBACTERIAL ACTIVITY OF MEDICINAL PLANTS TURMERIC, CHINNAMON, AND CLOVE AGAINST GM (+VE) AND GM (-VE) BACTERIA
}

\author{
MD ARIFUL ISLAM ${ }^{1 *}$, MD SIDDIQUL ISLAM ${ }^{1}$, MD ANWAR HOSSAIN ${ }^{1}$, SULTAN AHMED ${ }^{2}$, MD AKTARUZZAMAN ${ }^{1}$, \\ MD RASHEDUNNABI AKANDA ${ }^{1}$, MD MOWDUDUL HASAN TALHA ${ }^{1}$, ABDULLAH AL ZABIR ${ }^{3}$
}

${ }^{1}$ Department of Pharmacology and Toxicology, Sylhet Agricultural University, Bangladesh, ${ }^{2}$ Department of Microbiology and Immunology, Sylhet Agricultural University, Bangladesh, ${ }^{3}$ Department of Agricultural Statistics, Sylhet Agricultural University, Bangladesh Email: drariful.vet@gmail.com

Received: 18 May 2019, Revised and Accepted: 15 Jul 2019

\section{ABSTRACT}

Objective: Various diseases are caused by different pathogenic microorganisms. Antibiotics are being used for treatment of these infectious diseases, yet unpredictable utilization of it leads towards antibacterial resistance. It is required to discover better approaches to battle against antibacterial resistance. Therefore, the study aimed to detect antibacterial sensitivity of ethanol extracts of Curcuma longa (turmeric), Cinnamomum zeylanicum (clove) and Syzygium aromaticum (cinnamon) against Staphylococcus aureus and E coli.

Methods: Prior to sensitivity testing, ethanol oils were extracted by an electric blender and each of the bacteria strains were cultured onto blood agar plate. Antibacterial activity was tested by agar well diffusion method where three different concentrations (50 $\mu$ l, $75 \mu \mathrm{l}$ and $100 \mu \mathrm{l})$ of selected plants extract were used so far as to measure the inhibition zone. Inhibition zone of the ethanol extract of these plants were calculated where three were found to be sensitive against Staphylococcus aureus and $E$ coli.

Results: Greater inhibition zone $14.5 \mathrm{~mm}, 18.25 \mathrm{~mm}, 21.5 \mathrm{~mm}$ at100 $\mu \mathrm{l}$ against Syaphylococcus aureus in case of cinnamon whereas the least inhibition zone was showed by turmeric and it was $9.00 \mathrm{~mm}, 11.00 \mathrm{~mm}$, and $12.75 \mathrm{~mm}$ at $100 \mu$ l extract against E. coli.

Conclusion: Overall, all the ethanol extracts were found to effective against these two bacteria but cinnamon can be used as more effective antibacterial agent in both human and veterinary field after the toxicological test.

Keywords: Medicinal plants, Turmeric, Cinnamon, Clove, Bacteria, Antibiotic resistance

(C) 2019 The Authors. Published by Innovare Academic Sciences Pvt Ltd. This is an open-access article under the CC BY license (http://creativecommons.org/licenses/by/4.0/) DOI: http://dx.doi.org/10.22159/ijcpr.2019v11i5.35712

\section{INTRODUCTION}

Drug resistance is the most prime concern for both veterinary and human medicine expert despite the use of various types of antibiotics. Researchers are incessantly concerned with the high and growing number of multi-drug resistant bacteria caused due to uncontrolled use of antibiotics for treatment as well as to prevent different disease outbreaks. Consumers, food processors, and regulatory Agencies are also worried about the safety of foods containing antibiotic and its residual effect on human body. Therefore, there has been a growing interest in the identification and development of effective and nontoxic antimicrobial compounds using natural antibacterial compounds from medicinal plant [1-4].

Many medicinal plants around the world are being used as herbal remedies against many infectious diseases throughout the history of mankind [5]. Even today, medicinal plans are playing a sound role as therapeutic remedies for primary treatment in developing countries [6]. There are literally a large number of published research papers from around the world describing the antimicrobial activities of medicinal plants [7-10]. A study of the PubMed database (information from 1975 to 2005 , accessible on the Internet) created around 1360 reports in the scientific and medicinal research that describing the antimicrobial activities of different plant species and their synthetic constituents. Moreover, a study of the Napralert database, the world's biggest medicinal database housed inside the University of Illinois at Chicago, demonstrates that of the 58,850 plant species recorded in the database, 6,550 species have been tested for antimicrobial activity, of which right around 4000 species had ethno medical information supporting the utilization of these plants to treat infectious diseases $[7,11]$. The greater part of the plants had an action against a scope of microscopic part of organisms, parasites or Mycobacterium. Numerous medicinal plants have been tested against several strains of bacteria, the most widely recognized microbes utilized as a part of antibacterial tests include:
Escherichia coli, Enterococcus faecalis, Bacillus cereus, Bacillus subtillis, Chlamydia pneumonia, Staphylococcus aureus, Streptococcus pneumoniae, Klebsiella pneumoniae, Pseudomonas aeruginosa vancomycin resistant Enterococcus (VRE), and Helicobacter pylori [12].

Among medicinal plant, spices have been used from the very beginning of the invention of fire as a food additive. However, it's being used as folk medicine and preservatives from ancient time [13]. Bacteriostatic and bactericidal or antioxidant activity are the reasons to be used the spices as folk medicine [14] and generally recognized them to be safe for human body, maybe for their traditional use or for lack of documentation about the toxicity [1]. But, we need to go out from this traditional use and should look forward to using widely both in human and animal medicine field. Several studies on antibacterial plant have been done all over the world with different other plans. But, there is a lack of generalized study with the selected plants. So, the study has done to screen the antibacterial activity of Curcuma longa, Cinnamomum zeylanicum and Syzygiumaromaticum against two common bacteria species Escherichia coli and Staphylococcus aureus and illustrate the comparative potential of medicinal plants.

\section{MATERIALS AND METHODS}

\section{Selection of plant material}

Three medicinal plants were selected in this research for detection of antibacterial activity under in vitro conditions in the laboratory. The scientific name, local name, part used in the study and its traditional application have shown in table 1 . The plans were collected from different regions in Bangladesh based on their traditional application and claims. These plants were identified by Dept. of Pharmacology and Toxicology, Sylhet Agricultural University, Sylhet. These plants specimens have been deposited and preserved at the Laboratory of Microbiology, Sylhet Agricultural University, Sylhet for further procedure. 
Table 1: Medicinal plants tested for antibacterial activity

\begin{tabular}{llll}
\hline No. & Scientific name & Local name & Part used in the study \\
\hline 1 & Curcuma longa & Holud & Stem \\
2 & Cinnamomum zeylanicum & Daruchini & Bark \\
3 & Syzygium aromaticum & Lavang & Flower \\
\hline
\end{tabular}

\section{Preparation of plant extract}

The plant extract was prepared, according to Odey et al. (2012). Briefly, the medicinal plans after collection were thoroughly washed to remove debris and the earth remains. From these usable parts of the plans were separated and chopped into bits and allowed to dry under shade. The dried sample then blended for making them into powder form by electric Blender and preserved in airtight container. One hundred grams $(100 \mathrm{~g})$ of each powder was weighed using an electronic measuring balance. Each powder was differently soaked in $400 \mathrm{ml}$ of ethyl alcohol $(80 \% \mathrm{BDH})$, at a ratio of 1:4 (powder/solvent and was agitated using an electric blender. After that every blended mixture was poured into air-tight plastic container and kept in the refrigerator at $4{ }^{\circ} \mathrm{C}$ for $48 \mathrm{~h}$. The mixture then first filtered by cloth and then filtered by Whatman No 1 filter paper. The filtered solutions were stored in container and preserved in refrigerator for detection of antimicrobial activity.

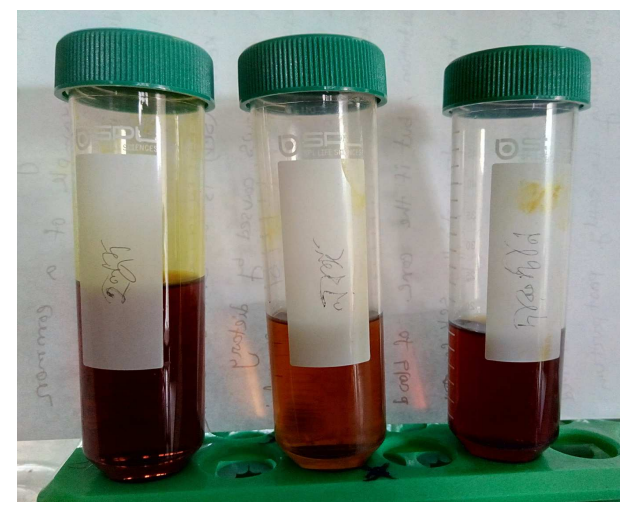

Fig. 1: Selected plant extracts

\section{Bacteria and bacteria culture}

Prior to sensitivity testing, Escherichia coli and Staphylococcus aureus strains were cultured onto Eosin Methylene Blue (EMB) and Mannitol Salt agar respectively and incubated for $24 \mathrm{~h}$ at $37^{\circ} \mathrm{C}$. A single colony was then cultured in $5 \mathrm{ml}$ Nutrient Broth for $4 \mathrm{~h}$ at $37^{\circ} \mathrm{C}$. The density of bacteria culture required for the test was adjusted to 0.5 McFarland standard, (1.0 x $108 \mathrm{CFU} / \mathrm{ml})$ measured using the Turbidometer (Oxoid, UK).

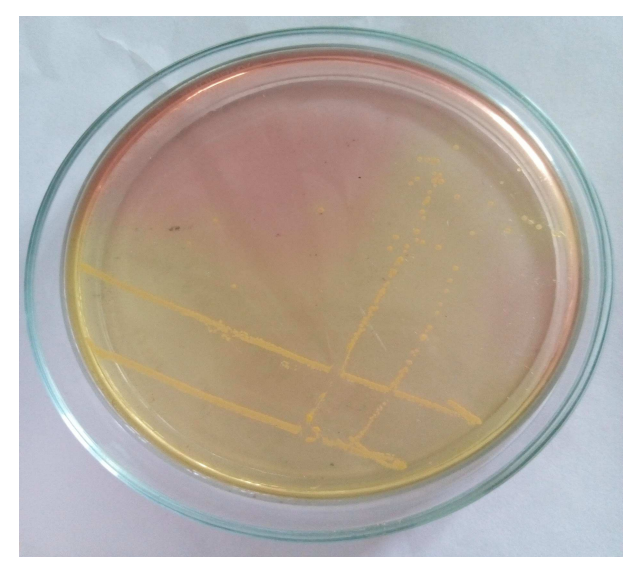

Fig. 2: Staphylococcus aureus

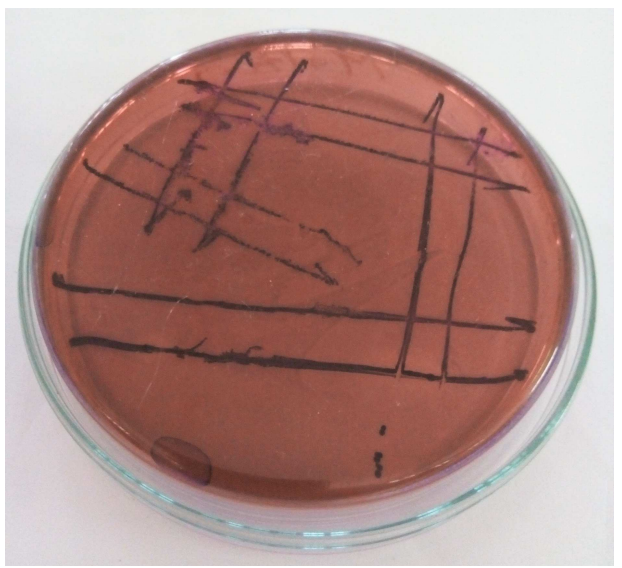

Fig. 3: Escherichia coli

\section{Screening for antibacterial activity}

Antibacterial activity was tested by agar well diffusion method where different concentrations of selected plant extract were used. The organisms were planted in sterile Petri plates using medium by softly mixing of $0.1 \mathrm{ml}$ of the $24 \mathrm{~h}$ fresh cultures alone with $35 \mathrm{ml}$ sterile liquid agar. $7 \mathrm{~mm}$ diameter wells were made using sterile borer after harding the agar of Petri plates. All wells were filled with $0.1 \mathrm{ml}$ of extract and then incubated at $37^{\circ} \mathrm{C}$ for $24 \mathrm{~h}$. The diameter of the inhibition zone around of each well was measured to detect the antibacterial activity. The experiment was done in triplicate and mean diameter of inhibition zones were recorded.

\section{Data analysis}

The data were analyzed as the means and the standard deviation of the means (means \pm SE) with analysis of variance (ANOVA) and means were separated using Duncan grouping in a statistical system (SAS-2007) software of computer program.

\section{RESULTS AND DISCUSSION}

\section{Evaluation of the antibacterial activity of Curcuma longa} (Turmeric)

The antibacterial effect of Curcuma longa (Turmeric) on E. coli and Staphylococcus aureus has been described in table 2. We used three different doses for each bacteria to measure the inhibition zone in the media. From the table we found that at $75 \mu \mathrm{l}$ level of ethanol extract of turmeric showed the highest inhibition zone in case of both bacteria. That it had been reduced in using the extract at $100 \mu \mathrm{l}$ where the inhibition zone was $10.75 \mathrm{~mm}$ and $9.5 \mathrm{~mm}$ respectively for E. coli and Staphylococcus aureus. There was no significant difference $(p>05)$ in antibacterial activity of turmeric. At $50 \mu \mathrm{l}$ turmeric showed $9.00 \mathrm{~mm}$ inhibition zone in the culture of $E$. coli wherein Staphylococcus aureus it was $8.5 \mathrm{~mm}$. The antimicrobial activity of $C$. longa has been reported in previous study. It was found that the C. longa has inhibitory effect against Pseudomonous aeruginosa [15, 16], Aeromonas hydrophila, Listeria monocytogenes and Salmonella typhimuriaum DT104 and methicillin-resistant Staphylococcus aureus [17]. In this study, the results showed antibacterial activity of $C$. longa ethanol extract against $E$. coli and Staphylococcus aureus. The result from this study may supported the antimicrobial activity and somehow the confirmation of antimicrobial activity of $C$. longa. Moreover, it may support the use of C. longa for antimicrobial treatment disease or prevention of bacteria growth. 
Table 2: Evaluation of antibacterial activity of Curcuma longa (Turmeric)

\begin{tabular}{lll}
\hline Concentration plant extract & E. coli & Staphylococcus aureus \\
\cline { 2 - 3 } & Zone of inhibition (mean \pm SD) $\mathbf{~ m m}$ & \\
\hline $50 \mu \mathrm{l}$ & $9.00^{\mathrm{b}} \pm 1.4142$ & $8.5^{\mathrm{a}} \pm 5.8023$ \\
$75 \mu \mathrm{l}$ & $11.00^{\mathrm{a}} \pm 2.1602$ & $10^{\mathrm{a}} \pm 1.1547$ \\
$100 \mu \mathrm{l}$ & $10.75^{\mathrm{c}} \pm 2.63$ & $9.5^{\mathrm{b}} \pm 6.6081$ \\
$P$-Value $($ At $\mathrm{p}<.05)$ & .389459 & .915656 \\
\hline
\end{tabular}

\section{Evaluation of the antibacterial activity of Cinnamomum zeylanicum (Cinnamon)}

Table 3 illustrated the effect of cinnamon on two different bacteria named E. coli and Staphylococcus aureus. It is clear from the table that cinnamon worked mostly on Staphylococcus aureus where there gradual increase through the rising the dose of the extract starting $14.5 \mathrm{~mm}$ inhibition zone at $50 \mu \mathrm{l}$ that reached to $21.5 \mathrm{~mm}$ inhibition zone at $100 \mu \mathrm{l}$. On the other hand, E. coli also showed sensitivity to cinamon though it is comparatively lower than Staphylococcus aureus. The inhibition zone, in that case, is $12.25,13.5$ and 15.75 respectively. There found significance difference $(\mathrm{p}<.05)$ in both bacteria.

The findings of this work were observed to be steady with the work done by [18] who indicated distinctive concentration of basic oil of cinnamon against Staphylococcus aureus. Moreover, [19] who discovered that cinnamon oil was powerful against E. coli (gram negative) and in his experiment proved that the fundamental oil of cinnamon produce inhibition zone against Staphylococcus aureus. These discoveries are additionally very comparable with the result of [20] revealing that cinnamon bark oil completely suppresses the development of some gram-positive and gram-negative microscopic organisms, growths [21]. As the agent, cinnamaldehyde, has ended up being especially powerful against a few types of gram-positive and gram-negative microbes [22-24]. It has been suggested that cinnamaldehyde and eugenol restrain generation of a basic compound by bacteria or potentially cause harm to the cell mass of microscopic organisms [25]. Along these lines, the high antibacterial activity of cinnamon oil is because of the presence of a high amount of cinnamaldehyde.

Table 3: Evaluation of the antibacterial activity of Cinnamomum zeylanicum (Cinnamon)

\begin{tabular}{lll}
\hline $\begin{array}{l}\text { Concentration } \\
\text { plant extract }\end{array}$ & E. coli & Staphylococcus aureus \\
\cline { 2 - 3 } & Zone of Inhibition (mean \pm SD) $\mathbf{~ m m}$ & \\
$75 \mu \mathrm{l}$ & $12.25^{\mathrm{a}} \pm 1.5$ & $14.5^{\mathrm{a}} \pm 2.3805$ \\
$100 \mu \mathrm{l}$ & $13.5^{\mathrm{a}} \pm 1.291$ & $18.25^{\mathrm{c}} \pm 2.7538$ \\
$P$-Value $($ At $\mathrm{p}<.05)$ & $15.75^{\mathrm{a}} \pm 1.2583$ & $21.5^{\mathrm{b}} \pm 3.1091$ \\
\hline
\end{tabular}

\section{Evaluation of antibacterial activity of Syzygium aromaticum (Clove)}

Table 4 provide us the information about the antibacterial sensitivity of E. coli and Staphylococcus aureus against clove. The table showed that the highest sensitivity found at $100 \mu \mathrm{l}$ dose against Staphylococcus aureus whilst the least in the case of E. coli in case of $50 \mu \mathrm{l}$ of ethanol extract. Comparatively Staphylococcus aureus is more sensitive to clove than $E$. coli to clove. There were significant differences $(\mathrm{p}<.05)$ in the case of both bacteria.

This finding is in agreement with those of other workers [27-28]. They reported that clove extracts showed activities in the range (concentrations) from 20 to $250 \mu \mathrm{g} / \mathrm{ml}$. The present data showed the effect of using clove oil both E. coli and Staphylococcus aureus bacteria. This data are agreed with some studies [29-32] and reported that a synergistic effect was observed for P. aeruginosa, which is resistant to 19 different antibiotics. This occurred during the association of antibiotics with extracts from clove, jambolan, pomegranate and thyme. Bisset (1994) reported that this effect was also observed for K. pneumoniae when $20 \mu \mathrm{g} / \mathrm{ml}$ of clove extract was combined to ampicillin. Also, the study [30] reported that the growth of Proteus spp. was inhibited when either clove extract (10 $\mu \mathrm{g} / \mathrm{ml})$ or eugenol $(5 \mu \mathrm{g} / \mathrm{ml})$ was combined to tetracycline.

Table 4: Evaluation of the antibacterial activity of Syzygium aromaticum (Clove)

\begin{tabular}{lll}
\hline Concentration plant extract & E. coli & Staphylococcus aureus \\
\cline { 2 - 3 } & Zone of inhibition (mean \pm SD) $\mathbf{~ m m}$ & \\
\hline $50 \mu \mathrm{l}$ & $9.75^{\mathrm{a}} \pm 1.7078$ & $10.5^{\mathrm{b}} \pm 1.7078$ \\
$75 \mu \mathrm{l}$ & $10.75^{\mathrm{a}} \pm 1.5$ & $13.25^{\mathrm{c}} \pm 1.2583$ \\
$100 \mu \mathrm{l}$ & $13.5^{\mathrm{c}} \pm 2.0817$ & $15.00^{\mathrm{a}} \pm 1.8257$ \\
$P$-Value $($ At $\mathrm{p}<.05)$ & .022848 & .01847 \\
\hline
\end{tabular}

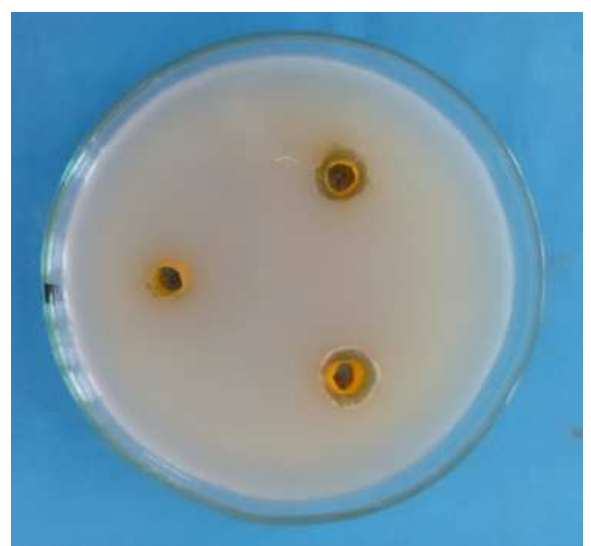

Fig. 4: Inhibition zone of Curcuma longa

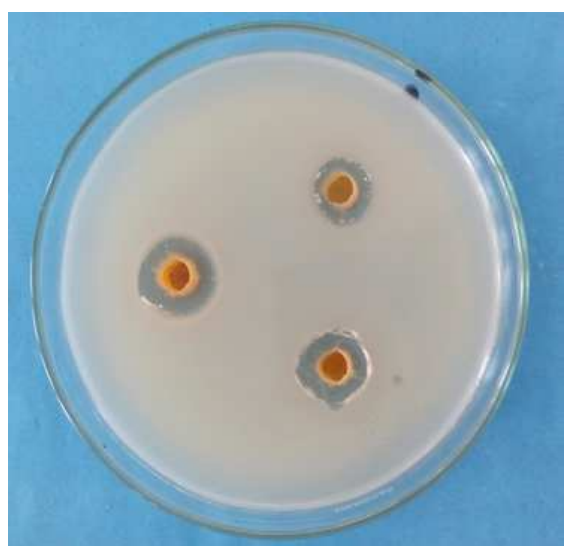

Fig. 5: Inhibition zone of Cinnamomum zeylanicum 


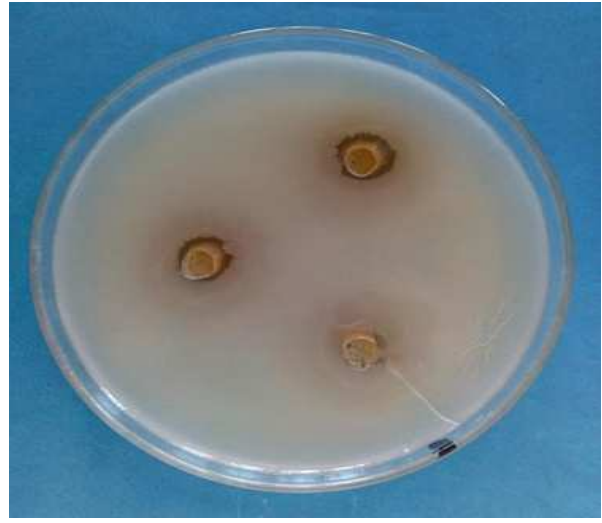

Fig. 6: Inhibition zone of Syzygiumaromaticum

\section{CONCLUSION}

Inhibition zone of the ethanol extract of these plants was calculated where three were found to be sensitive against Syaphylococcus aureus and E coli. However, the ethanol extract of Cinnamomum zeylanicum was found to have more effective antimicrobial activity showing its maximum efficacy for both bacteria. Data from the literature, as well as our results, reveal the great potential of plant oils as antibacterial agent, in spite of the fact that they have not been completely investigated, more studies need to be conducted. Therefore, our results revealed the importance of plant oils when associated with antibiotics, to control resistant bacteria, which are becoming a threat to human health.

\section{AUTHORS CONTRIBUTIONS}

All the author have contributed equally

\section{CONFLICT OF INTERESTS}

Declare none

\section{REFERENCES}

1. Smid EJ, Gorris LG. Natural antimicrobials for food preservation. Food Science and Technology-New York: Marcel Dekker; 1999. p. 285-308.

2. Islam MA, Hossain MN, Chokraborti SS, Rahman S, Tasnim A, Al Zabir A. Socio-economic profile of goat rearing farmers and their management practices in sylhet, Bangladesh. J Agric Ecol Res Int 2018;1:1-0.

3. Chokraborti SS, Baset MA, Al Zabir A, Islam MA. Are Dairy Farmers of Haor (Wetland) Areas Food Secured? Asian J Agric Extension Econ Sociol 2019;29:1-8.

4. Ahmed S, Uddin MJ, Islam MA, Haque ME. Effect of Graded Levels of Slaughter House Residues on Growth Performance and Haematological Parameters in Broiler Chicken's Ration. Asian Res J Agric 2018;9:1-8.

5. Schmidt B, Ribnicky DM, Poulev A, Logendra S, Cefalu WT, Raskin I. A natural history of botanical therapeutics. Metabolism 2008;57:S3-9.

6. Zakaria M. Isolation and characterization of active compounds from medicinal plants. Asia Pacific J Pharmacol 1991;6:15-20.

7. Mahady GB. Medicinal plants for the prevention and treatment of bacterial infections. Curr Pharm Design 2005;11:2405-27.

8. Kalemba DA, Kunicka A. Antibacterial and antifungal properties of essential oils. Curr Med Chem 2003;10:813-29.

9. Rates SM. Plants as a source of drugs. Toxicon 2001;39:603-13.

10. Subapriya R, Nagini S. Medicinal properties of neem leaves: a review. Curr Med Chem Anti-Cancer Agents 2005;5:149-56.

11. Farnsworth NR. NAPRALERT database. University of Illinois at Chicago: Chicago, IL, production (an online database available directly through the University of Illinois at Chicago or through the Scientific and Technical Network [STN] of Chemical Abstracts Services); 2004.

12. Martin KW, Ernst E. Herbal medicines for the treatment of bacterial infections: a review of controlled clinical trials. J Antimicrob Chemother 2003;51:241-6.

13. Clavero MR, Monk JD, Beuchat LR, Doyle MP, Brackett RE. Inactivation of escherichia coli $0157: H 7$, salmonellae, and campylobacter jejuni in raw ground beef by gamma irradiation. Appl Environ Microbiol 1994;60:2069-75.

14. Beuchat LR, Golden DA. Antimicrobials occurring naturally in foods. Food Technology (USA). 1989;43:134-42.

15. Negi PS, Jayaprakasha GK, Jagan Mohan Rao L, Sakariah KK. Antibacterial activity of turmeric oil: a byproduct from curcumin manufacture. J Agric Food Chem 1999;47:4297-300.

16. Rudrappa T, Bais HP. Curcumin, a known phenolic from Curcuma longa, attenuates the virulence of Pseudomonas aeruginosa PAO1 in whole plant and animal pathogenicity models. J Agric Food Chem 2008;56:1955-62.

17. Kim KJ, Yu HH, Cha JD, Seo SJ, Choi NY, You YO. Antibacterial activity of curcuma longa L. against methicillin-resistant staphylococcus aureus. Phytother Res: Int J Devoted Pharmacol Toxicol Evaluation Natural Product Derivatives 2005;19:599-604.

18. Yuste J, Fung DY. Evaluation of salmonella typhimurium, yersinia enterocolitica and staphylococcus aureus counts in apple juice with cinnamon, by conventional media and thin agar layer method. Food Microbiol 2003;20:365-70.

19. Friedman M, Henika PR, Mandrell RE. Bactericidal activities of plant essential oils and some of their isolated constituents against campylobacter jejuni, Escherichia coli, Listeria monocytogenes, and Salmonella enterica. J Food Protection 2002;65:1545-60.

20. Chao SC, Young DG, Oberg CJ. Screening for inhibitory activity of essential oils on selected bacteria, fungi and viruses. J Essential Oil Res 2000;12:639-49.

21. Gutierrez J, Barry Ryan C, Bourke P. The antimicrobial efficacy of plant essential oil combinations and interactions with food ingredients. Int J Food Microbiol 2008;124:91-7.

22. Jantan IB, Karim Moharam BA, Santhanam J, Jamal JA. Correlation between chemical composition and antifungal activity of the essential oils of eight cinnamomum. Species Pharm Biol 2008;46:406-12.

23. Shahverdi AR, Monsef Esfahani HR, Tavasoli F, Zaheri A, Mirjani $R$. Trans-cinnamaldehyde from cinnamomumzeylanicum bark essential oil reduces the clindamycin resistance of clostridium difficile in vitro. J Food Sci 2007;72:S055-8.

24. Shan B, Cai YZ, Brooks JD, Corke H. Antibacterial properties and major bioactive components of cinnamon stick (Cinnamomumburmannii): activity against foodborne pathogenic bacteria. J Agric Food Chem 2007;55:5484-90.

25. Helander IM, Alakomi HL, Latva Kala K, Mattila Sandholm T, Pol I, Smid EJ, et al. Characterization of the action of selected essential oil components on gram-negative bacteria. J Agric Food Chem 1998;46:3590-5.

26. Di Pasqua R, Betts G, Hoskins N, Edwards M, Ercolini D, Mauriello G. Membrane toxicity of antimicrobial compounds from essential oils. J Agric Food Chem 2007;55:4863-70.

27. Nascimento GG, Locatelli J, Freitas PC, Silva GL. Antibacterial activity of plant extracts and phytochemicals on antibioticresistant bacteria. Brazilian J Microbiol 2000;31:247-56.

28. Saxena G, McCutcheon AR, Farmer S, Towers GH, Hancock RE. Antimicrobial constituents of Rhusglabra. J Ethnopharmacol 1994;42:95-9.

29. Bisset NG. Herbal drugs and phytopharmaceuticals: a handbook for practice on a scientific basis. Medpharm Scientific Publishers; 1994. p. 704.

30. Carvalho V, Melo VM, Aguiar A, Matos FS. Toxicity evaluation of medicinal plant extracts by the brine shrump (Arthenussalina Leah) biossay. Cienciae Cultura 1988;40:1109-11.

31. Chandler RF, Hooper SN, Harvey MJ. Ethnobotany and phytochemistry of yarrow, Achilleamillefolium, Compositae. Economic Bot 1982;36:203-23. 